УдК 338.48-611

\title{
РОЗВИТОК НОСТАЛЬГІЧНОГО ТУРИЗМУ В РАМКАХ ФЕСТИВАЛЬНОГО РУХУ
}

\section{DEVELOPMENT OF NOSTALGIC TOURISM WITHIN THE FRAMEWORK OF THE FESTIVAL MOVEMENT}

\author{
Пудровська Марина Михайлівна \\ аспірант, \\ Харківський національний економічний університет \\ імені Семена Кузнеця \\ ORCID: https://orcid.org/0000-0001-5757-4206
}

Pudrovska Maryna

Simon Kuznets Kharkiv National University of Economics

\begin{abstract}
У статті розглянуто основні тенденції розвитку ностальгічного туризму в контексті посилення його ролі у підтримці та активізації різних контактів з іноземними співвітчизниками в рамках розвитку фестивального руху. Фестивалі є явищем, що швидко розвивається, саме тому вони часто вивчаються в різних науках. Вони відіграють важливу роль у розвитку туризму; тому важливо провести комплексне вивчення фрестивалів в рамках ностальгічного туризму. Головне в фестивалі - це відчуття свята, яке він дарує всім своїм учасникам і відвідувачам. Саме ця атмосфера приваблює туристів з усього світу, що визначає ексклюзивність фрестивалів серед інших напрямків ностальгічного туризму. Ностальгічні поїздки від відвідування фестивалю можуть бути досить привабливими на туристичному ринку, особливо для молоді. Фестивалі тісно пов'язані з людьми і широко сприймаються людською культурою. Що стосується туризму, то фрестивалі вивчаються як частина культурної, міської та туристичної сфрер. Організація фрестивалів має велике значення для збереження єдиного культурного простору країни. При виборі місця проведення фрестивалів зазвичай керуються історичним минулим цих місць. Наприклад, для фестивалю, присвяченого пам'яті про Другу світову війну, краще підійде парк, де є обеліск або пам'ятник, встановлений в пам'ять про Другу світову війну. Необхідно розробити ідею і план, пов'язавши їх з історичними подіями, це створить правильний настрій, який найбільш точно відіб'ється на цілі та ідеї фестивалю. Як приклад розглядається єврейський фестиваль Jewish Open Space, який майже щороку відвідує величезна кількість туристів, в тому числі й ностальгічних. Також в статті розглянуто основний потенціал клієнтської бази споживачів ностальгічного туризму. Представлені статистичні данні міграції українських євреїв закордон. Зроблено висновок, що фрестивальний рух був не тільки одним з фракторів збереження елементів етнічної культури єврейського народу, а й сприяв активізації розвитку туристичної галузі.

Ключові слова: ностальгічний туризм, фрестивальний рух, етнічна культура, діаспора, єврейський народ.
\end{abstract}

В статье исследуются основные тенденции развития ностальгического туризма в контексте усиления его роли в поддержании и активизации разнообразных контактов с зарубежными соотечественниками в рамках развития фрестивального движения. Фестивали - явление стремительно развивающееся, именно поэтому их часто изучают в разных науках. Они играют важную роль в развитии туризма; поэтому важно провести комплексное изучение фестивалей в рамках ностальгического туризма. Главное в фестивале - это ощущение праздника, который он дарит всем своим участникам и посетителям. Именно такая атмоссрера привлекает туристов со всего мира, что обуславливает исключительность фрестивалей в числе прочих направлений ностальгического туризма. Ностальгические поездки с посещения фрестиваля могут оказаться достаточно привлекательными на туристическом рынке особенно для молодежи. Фестивали тесно связаны с людьми и широко воспринимается человеческой культурой. Что касается туризма, то фестивали изучаются как часть культурной, городской и туристической сфер. Организация фрестивалей имеет огромное значение для сохранения единого культурного пространства страны. При выборе места проведения фрестивалей обычно руководствуются историческим прошлым этих мест. Так, например, для проведения фестиваля, посвященного памяти ВОВ, лучше подойдет парк, где есть обелиск или памятник, установленный в память о ВОВ. Необходимо разработать идею и план, связав их с историческими событиями, это создаст правильное настроение, которое будет наиболее верно отображать цели и идеи фестиваля. Как пример был рассмотрен еврейский фестиваль Jewish Open Space, который почти ежегодно посещаю огромное количество туристов, в том числе и ностальгических. Так в статье рассмотрены основной потенциал клиентской базы потребителей носталь- 
гических туров. Представленные статистические данные миграции украинских евреев за границу. Сделан вывод о том, что фестивальное движение явилось не только одним из фракторов сохранения элементов этнической культуры еврейского народа, но и способствовало активизации развитию туристической сореры.

Ключевые слова: ностальгический туризм, фестивальное движение, этническая культура, диаспора, еврейский народ.

The article examines the main trends in the development of nostalgic tourism in the context of strengthening its role in maintaining and intensifying various contacts with foreign compatriots in the framework of the development of the festival movement. Festivals are a rapidly developing phenomenon, that is why they are often studied in different sciences. They play an important role in the development of tourism; therefore, it is important to conduct a comprehensive study of festivals within the framework of nostalgic tourism. The main thing in the festival is the feeling of celebration, which it gives to all its participants and visitors. It is the atmosphere that attracts tourists from all over the world, which determines the exclusivity of festivals among other areas of nostalgic tourism. Nostalgic trips with a visit the festival can be quite attractive in the tourist market, especially for young people. Festivals are closely related to people and are widely perceived by human culture. As for tourism, festivals are studied as part of the cultural, urban and tourist spheres. The organization of festivals has great importance for the conservation of a unique cultural space of the country. When choosing a venue for festivals, they are usually guided by the historical past of these places. For example, for a festival dedicated to the memory of the Second World War, a park where there is an obelisk or a monument installed in memory of the Second World War is better suited. It is necessary to develop an idea and a plan, linking them with historical events, this will create the right mood that will most accurately reflect the goals and ideas of the festival. As an example, the festival "Jewish Open Space", which is visited almost annually by a huge number of tourists, including nostalgic ones, was considered. The article also examines the main potential of the clients base of consumers of nostalgic tours. Statistical data on the migration of Ukrainian Jews abroad is presented. It is concluded that the festival movement was not only one of the factors of preserving the elements of the ethnic culture of the Jewish people, but also contributed to the activation of the development of the tourism sector.

Keywords: nostalgic tourism, festival movement, ethnic culture, diaspora, Jewish people.

Постановка проблеми. Сьогодні найважливішим завданням сучасної культурної політики $€$ пошук оптимальних фрорм і способів організації систематичних контактів у сорері культури, що сприяють інтеграції та стабілізації суспільних відносин. I в цьому плані досить плідною і динамічно розвиненою формою міжкультурної комунікації $€$ орестивалі культур, різні кастинги та конкурси, в проведенні яких, як правило, беруть участь представники різних етносів і релігійних конфресій. Основне завдання сучасного фрестивального руху - встановлення міжнаціональних культурних контактів, формування гуманістичного мислення, вироблення гуманістичних ідеалів культури. Фестиваль як явище мистецького життя відрізняється особливою атмосфрерою свята, орієнтацією на показ кращих художніх колективів і виконавців, оригінальністю пропозицій репертуару, відмінного від репертуару стаціонарних колективів. Основне завдання фестивалю - внести нове у культурне життя країни, регіону, міста, створити максимально широке поле тяжіння як для профресіоналів в області театру і музики, так і для рядових глядачів і слухачів.

На сучасному етапі все частіше обговорюється тема впливу фестивалів і фрестивалізації на економічний розвиток регіонів та країни в цілому. При цьому срестивалі розглядаються перш за все в призмі територіального маркетингу і туризму. Так, вважається, що фестивалі можуть бути інструментом підвищення туристичної привабливості території за рахунок того, що вони є відображенням місцевої культури, потенційно незнайомої і в деяких випадках екзотичної, тому цікавою для зовнішніх цільових аудиторій. За допомогою участі у фрестивалях, туристи отримують можливість зануритися в незвичайну і нову для них атмоссреру, випробувати яскраві емоції під враженням від отриманого ними досвіду, а також встановити довгострокові контакти 3 людьми зі схожими інтересами. Дані спостереження також цікаві з точки зору брендингу території як процесу донесення переваг, цінностей, позитивних образів про території до цільових груп іï бренду, ключовими з яких і $€$ туристи і місцеве населення.

Слід зазначити, що інтерес до міжнародного фрестивального руху значно зріс у 1990-і рр., так як в умовах глобалізації та інтенсивного освоєння високотехнологічних процесів, 3 одного боку, і виникнення осередків міжнаціональної напруги, часто призводять до відкритих військових конфрліктів - 3 іншого, діалог культур може стати фактором стабілізації та гармонізації міжнаціональних відносин. Нація, яка закриває двері для культурного спілкування, приречена на культурний занепад і духовну ентропію. Здатність одного народу освоювати досягнення іншого - най- 
важливіший показник його духовного здоров'я і життєздатності його власної культури. Саме у взаємодії у ссрері культури і визначається взаємозв'язок розвитку і взаємовпливу фестивального руху і ностальгічного туризму.

Аналіз останніх досліджень і публікацій. щодо визначення поняття «ностальгічний туризм» немає єдиної думки. Відповідно до прийнятого в міжнародній класифікації визначенням, ностальгічний туризм розглядається як поняття, синонімічне етнічному [1]. Етнотуризм, в свою чергу, це подорож, метою якого $€$ знайомство з історією, культурою, побутом, місцем проживання того чи іншого народу.

Обговорення питань ностальгії і проектування розвитку суспільства дали поштовх для становлення нового виду туризму - ностальгічного. Існує кілька підходів до розумінню того, що мається на увазі під ностальгічним туризмом. Частина експертів визначає його як подорож туристів на територію їх проживання в минулому, для зустрічі з друзями дитинства, родичами [2]. Інші експерти розуміють ностальгічний туризм ширше, розцінюючи його як поїздку з метою ознайомлення $з$ історичною батьківщиною [3].

Ностальгічний туризм втілюється в таких видах, як етнічний, ретроспективний, туризм співвітчизників і діаспор, туризм спадщини. Основним мотивом відвідування історичної малої батьківщини $є$ ностальгія - туга за Батьківщиною, місцями історичного походження і проживання, природою, мовою, звичаями, традиціями. Ностальгічний туризм у всіх своїх проявах пов'язаний з селективним збереженням фррагментів соціальної пам'яті і реконструюванням минулого. Ностальгічний туризм ідентичний подорожі по метасрізичній батьківщині, яка розташовується не в сорері території, а в сорері культури, що робить можливим невпинне генерування нових фрорм, що вміщають в її простір і етнос, і групу, і конкретну людину.

Виділення невирішених раніше частин загальної проблеми. Проведення фестивалів має велике значення для збереження єдиного культурного простору країни. Фестивальний рух збагачує туристичну діяльність за кількома напрямками: розширює асортимент пропонованих туристичних продуктів в рамках ностальгічного туризму, підвищує привабливість регіону, сприяє підвищенню культурного рівня туристів, поповненню їх інтелектуального багажу та розширення горизонтів. Таким чином, існує необхідність довести доцільність впливу фрестивалів на фрормування ностальгічних турів.
Формулювання цілей статті (постановка завдання). Метою статті $€$ поглиблення теоретичного підґрунтя вивчення впливу фрестивалів на розвиток ностальгічного туризму в Україні, визначення особливостей та перспектив використання фрестивалів у туристичній діяльності.

Виклад основного матеріалу дослідження. Фестивалі - події, які досить легко просуваються, концентрують в собі певні естетичні враження і проводяться в певному місці і в певний час. Фестивалі є корисним інструментом для виробництва та просування певного набору бажаних вражень. Особливі процес взаємодії і взаємовпливу фестивального руху і ностальгічного туризму можна простежити на прикладі єврейського народу.

Останнім часом у зовнішній політиці України чітко проявився акцент на фрормування тісних всебічних зв'язків з численними співвітчизниками, розселення в різних регіонах земної кулі. У нинішніх умовах ностальгічний туризм покликаний зіграти важливу роль у підтримці і активізації різноманітних контактів з зарубіжними країнами, збереження почуття приналежності до єдиного геоінфрормаційного і економічного простору, причетності до спільної історичної долі.

Еміграція породжує таке явище як ностальгія, яке важко подолати, і воно пов'язане зі спогадами і тугою за втраченим. Найбільші потоки ностальгічних туристів, як не дивно етнічні українські євреї, в основному - ізраїльтяни. Ностальгічні тури стали однією з основних різновидів туризму, котрі приваблюють ізраїльтян в Україну.

Євреї - давній семітський народ, що походить від населення стародавнього Ізраїльського та Юдейського царств. Євреї живуть у багатьох країнах світу (з 1948 року існує відновлена єврейська держава Ізраїль) [4]. Євреї оселились на землях сучасної України ще в язичницькі, дохристиянські часи. Про їхнє перебування в Криму, куди вони переселилися з Малої Азії та Кавказу, свідчать надгробні написи I-II ст. до н. е. У перші роки радянської влади в Україні діяли сотні єврейських шкіл, синагог, єшив, ремісничих училищ, видавалися єврейські газети, книги, журнали. Тільки в Одесі були два єврейські інститути. Діяли єврейські колгоспи, кабінети єврейської культури. У 1920-х роках в Україні мешкало близько 2 млн євреїв, напередодні Другої світової війни - до 3 млн. Внаслідок міграційних процесів чисельність євреїв в Україні значно зменшилася і на сьогодні в Україні проживає 
лише 43000 євреїв. До нашого часу, крім деяких кримських, єврейські сільські поселення не збереглися.

Загальновідомим фрактом $є$ те, що більша частина цього народу була змушена покинути свою батьківщину і протягом багатьох років будувати своє життя в різних країнах світу. В той же час в нашій країні починаючи з 90-х рр. XX ст. позначилися процеси відродження інтересу до історичних і етнічних коренів, зростання етнічної самосвідомості, прагнення до відродженню своєї самобутності.

3 початку 90-х рр., коли почалася масова імміграція євреїв до Ізраїлю 3 республік колишнього СРСР, населення країни збільшилося майже на $30 \%$. У перші роки цієї хвилі імміграції приріст становив від 5\% до 6\% щорічно. У 1997 році чисельність євреїв в Ізраїлі зросла на 86 тис. чоловік, причому 60\% приросту відбувалося за рахунок нових іммігрантів, і лише $40 \%$ - за рахунок новонароджених у корінних ізраїльтян. Найбільша субетнічна група - вихідці 3 колишнього СРСР - 1,1 млн. чоловік. Імміграція 3 інших країн не грає настільки суттєвої ролі в демографрічній динаміці, як у період з 1989 по 1999 роки. Зараз 86\% зростання ізраїльського населення припадає на природний приріст і лише $14 \%$ - на імміграцію.

Реальна еміграція євреїв з України значно більша за офріційну (табл. 1), тому що Держкомстат не в змозі врахувати ні нелегальну еміграцію початку 90-х років, особливо в ФРН, ні такий процес, як зміна статусу туристів в Ізраїлі при їх неповерненні в Україну. Нижче спробуємо врахувати останній фрактор.

Еміграція євреїв з України (1989-2001)

\begin{tabular}{|c|c|c|c|c|c|c|c|c|c|c|c|c|c|}
\hline Рік & 1994 & 1995 & \multicolumn{2}{|c|}{1996} & \multicolumn{2}{|c|}{1997} & \multicolumn{2}{|c|}{1998} & \multicolumn{2}{|c|}{1999} & \multicolumn{2}{|c|}{2000} & 2001 \\
\hline $\begin{array}{l}\text { Кількість мігрантів-євреїв } \\
3 \text { України, чол. }\end{array}$ & 28306 & 23857 & \multicolumn{2}{|c|}{20493} & \multicolumn{2}{|c|}{15924} & \multicolumn{2}{|c|}{11550} & \multicolumn{2}{|c|}{12087} & \multicolumn{2}{|c|}{9859} & 6715 \\
\hline США & 9254 & 5774 & \multicolumn{2}{|c|}{4890} & \multicolumn{2}{|c|}{3291} & \multicolumn{2}{|c|}{1434} & \multicolumn{2}{|c|}{1133} & \multicolumn{2}{|c|}{941} & 625 \\
\hline ФРН (Німеччина) & 3838 & 4079 & \multicolumn{2}{|c|}{4085} & \multicolumn{2}{|c|}{3776} & \multicolumn{2}{|c|}{4012} & \multicolumn{2}{|c|}{4050} & \multicolumn{2}{|c|}{3693} & 3005 \\
\hline Ізраїль & 13840 & 12216 & \multicolumn{2}{|c|}{10200} & \multicolumn{2}{|c|}{8115} & \multicolumn{2}{|c|}{5636} & \multicolumn{2}{|c|}{6611} & \multicolumn{2}{|c|}{4993} & 2906 \\
\hline Канада & - & 120 & \multicolumn{2}{|c|}{119} & \multicolumn{2}{|c|}{101} & \multicolumn{2}{|c|}{72} & \multicolumn{2}{|c|}{55} & \multicolumn{2}{|c|}{28} & 43 \\
\hline Австралія & - & 170 & \multicolumn{2}{|c|}{126} & \multicolumn{2}{|c|}{87} & \multicolumn{2}{|c|}{0} & \multicolumn{2}{|c|}{16} & 1( & & 6 \\
\hline Росія & 900 & 831 & 79 & & 4 & & 28 & & 14 & & 14 & & 88 \\
\hline Білорусія & - & 43 & 7 & & 1 & & 1 & & 6 & & 2 & & 4 \\
\hline Молдова & - & 42 & 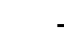 & & 1 & & 5 & & 8 & & 1 & & 5 \\
\hline Балтія & - & 11 & 1 & & . & & 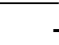 & & - & & - & & 4 \\
\hline Без вказання країни & - & - & 2 & & & & 1 & & - & & - & & - \\
\hline Інші країни & 474 & 571 & 23 & & & & 8 & & 6 & & 4 & & 29 \\
\hline Роки & & & & 19 & & 19 & & & & 19 & & 198 & $9-2001$ \\
\hline $\begin{array}{l}\text { Еміграція з України (без } \\
\text { по країнах), чол. }\end{array}$ & บліз & & & & & & & & & 2 & & & 1704 \\
\hline
\end{tabular}

\begin{tabular}{|l|c|c|c|c|c|c|c|}
\hline \multicolumn{1}{|c|}{ Рік } & $\mathbf{1 9 9 4 - 2 0 0 1}$ & $\mathbf{2 0 0 2}$ & $\mathbf{2 0 0 3}$ & $\mathbf{2 0 0 4}$ & $\mathbf{2 0 0 5}$ & $\mathbf{1 9 9 4 - 2 0 0 5}$ & $\mathbf{1 9 8 9 - 2 0 0 5}$ \\
\hline $\begin{array}{l}\text { Кількість мігрантів-євреїв } \\
\text { 3 України, чол. }\end{array}$ & 128791 & 4074 & 2692 & 1699 & 759 & 138015 & 300917 \\
\hline США & 27342 & 217 & 237 & 94 & 16 & 27906 & Н/д \\
\hline ФРН & 30538 & 2514 & 1653 & 927 & 332 & 35964 & Н/д \\
\hline Ізраїль & 64517 & 1220 & 726 & 404 & 333 & 67200 & Н/д \\
\hline Канада & 538 & 25 & 3 & 6 & 3 & 575 & Н/д \\
\hline Австралія & 415 & 1 & 2 & 4 & 4 & 426 & Н/д \\
\hline Росія & 3613 & 61 & 56 & 33 & 31 & 3794 & Н/д \\
\hline Білорусія & 76 & 3 & 1 & 1 & 0 & 81 & Н/д \\
\hline Молдова & 80 & 1 & 1 & 0 & 0 & 82 & Н/д \\
\hline Балтія & 26 & 43 & 0 & 2 & 0 & 71 & н/д \\
\hline Без вказання країни & 44 & 0 & 0 & 0 & 0 & 44 & Н/д \\
\hline Інші країни & 1602 & 0 & 13 & 228 & 40 & 1883 & н/д \\
\hline
\end{tabular}

Таблиця 1 
Аналіз процесу еміграції показує, що за період 1994-2001 рр. половину еміграції єврейського народу склала репатріація до Ізраїлю, $21,2 \%$ - еміграція в США, 23,7\% - в ФРН, тобто переважна кількість євреїв їдуть в зазначені три держави. Якщо подивитися на динаміку еміграційних процесів, то виявиться, що в 1994 році репатріація домінувала над іншими еміграційними тенденціями, то в 2001 році вперше за досліджуваний період щорічний обсяг еміграції в ФРН перевищив обсяг репатріації.

Стабільна еміграція євреїв України в ФРН пов'язана 3 великим накопиченим потенціалом отриманих дозволів (близько 30 тисяч), значними термінами очікування дозволів (3-5 років) і суттєвої соціальним захистом єврейських емігрантів в ФРН.

Звертає на себе увагу також значне зменшення річних обсягів еміграції в США в останні роки в 15 разів, що пов'язано, перш за все, 3 новими обмеженнями на в"їзд в цю країну.

Незважаючи на усі труднощі, євреї все ж зуміли зберегти свою мову, багату культуру і традиції. 3 середини 1980-х рр. в зв'язку 3 процесами перебудови і демократизації стали активізуватися зв'язку з зарубіжними співвітчизниками. Назріла необхідність створення координуючої організації, яка б зайнялася питаннями об'єднання єврейського народу, які проживають в різних країнах. 3 цією метою стали проводитись різноманітні культурні заходи по всій країні. Найбільш маштабним на сьогодні $\epsilon$ Jewish Open Space.

Jewish Open Space - щорічний молодіжний фестиваль єврейської культури, який проходить в Маріїнському парку Києва з ініціативи Київської єврейської месіанської общини (КЕMO) [6]. Він приурочений до осінніх єврейських свят. Фестиваль Jewish Open Space opiєнтований в основному на молодь, але в його програмі є маса заходів для дорослих та дітей, головне завдання яких - ближче познайомити відвідувачів фрестивалю з єврейською культурою та допомогти їм добре провести час. На фрестивалі діє шість тематичних платорорм, кожна $з$ яких пропонує набір захоплюючих і пізнавальних активностей: «Хобі», «Розвиток», «Освіта», «Сім'я», «Хесед» (благодійність) і «Стиль життя». Всього платфрорми представляють кілька десятків різних проектів 3 відкритою реєстрацією, від квестів, вікторин та майстер-класів до театральних постановок і благодійних розпродажів. Крім тематичних проектів в програму Jewish Open Space входять концерти в амсрітеатрі з клейзмерською музикою і єврейськими танцями, театральні вистави, кінопокази, квести, фротозони, спеціальна єврейська молитва для бажаючих, а також конкурси та розіграші призів і подарунків. Деякі із заходів присвячені єврейській культурі в цілому, а деякі - осіннім єврейським святам і постам. У 2017 р. фрестиваль відвідали близько 8 тисяч осіб, причому не тільки з Києва та інших міст України, а й з Білорусі, Фінляндії, США. Вхід на фрестиваль традиційно безкоштовний, фрестиваль проводиться щорічно у вересні з 2014 р. У 2020 фрестиваль не проводився через пандемію COVID-19, але відновив свою роботу із дотриманням необхідних застережних заходів у 2021 р.

3 позиції «споживання» фрестивалів очевидний фракт необхідності фрізичної присутності споживача на території проведення срестивалю. Отже, фрестивалізація як послідовне явище прив'язує «виробництво» $\mathrm{i}$ «споживання» фрестивалів до конкретних територій, спонукаючи людей проводити там більше часу, що, в свою чергу, передбачає оплату ними житла, харчування тощо, приносячи економічні вигоди території.

Відвідувачі фрестивалю отримають можливість дізнатися більше про життя національних меншин в Україні, про суспільну та виховну діяльність, які зазвичай підтримуються у великих громадах (таких, наприклад, як єврейська). Це чудова можливість побачити, як автентичні національні традиції природно інтегровані в сучасний світ.

Висновки. У країнах Західної Європи, США, Ізраїлі, Канаді та інших країнах проживає велика кількість вихідців з України та їх нащадків. Багато з них часто відвідують свою історичну батьківщину. Важливою частиною заходів з розвитку туризму в Україні повинна стати розробка спеціальних пропозицій для даної категорії туристів. Тематичні екскурсії дозволять іноземним туристам познайомитися з минулим своїх предків, їхньою культурою, дізнатися про знаменитих вихідців 3 країни, відвідати місця, пов'язані 3 історією різних народів, меморіальні комплекси, культові об'єкти тощо; взаємодіяти з представниками діаспори за кордоном і національними громадами на території України. Окрім цього, орестиваль може бути чудовим приводом відвідати далеку Батьківщину и провести гарно час. До того ж це привабить значну кількість молоді.

Jewish Open Space простір - це можливість побачити, наскільки різноманітною може бути Україна, і відчути, як справжня спадщина різних народів, що живуть у нашій країні, зба- 
гачує загальну культуру, і може стати прикладом для організації інших подібних заходів.

У нинішніх умовах ностальгічний туризм в рамках розвитку фестивального руху активізує контакти з зарубіжними співвітчизниками.
Проведення фрестивалів не тільки є одним 3 фракторів збереження елементів етнічної культури різних народів, але і може сприяти залученню в регіон фінансових коштів і оздоровленню економічного стану в регіоні та країні.

\section{СПИСОК ВИКОРИСТАНИХ ДЖЕРЕЛ:}

1. Кляп М.П. Сучасні різновиди туризму : навчальний посібник. Київ : Знання, 2011. 334 с.

2. Пуцентейло П.Р. Економіка і організація туристично-готельного підприємництва : навчальний посібник. Київ : Центр учбової літератури, 2007. 344 с.

3. Tomczewska-Popowycz Natalia. Етнічний туризм та інші близькі форми туризму в східноєвропейській літературі. Przegląd Wschodnioeuropejski. 2017. Vol. 8. Nr 1 (2017). S. 271-280.

4. Вікіпедія. URL: www.uk.wikipedia.org/wiki/€вреї

5. Офріційний сайт фестивалю. URL: www.jewishpeople.in.ua

6. Асоціація єврейських організацій та общин України. URL: www.vaadua.org

7. Стратегія повернення українців. URL: www.zn.ua

\section{REFERENCES:}

1. Klyap M.P. (2011) Suchasni riznovydy turyzmu: navchalniy posibnik [Modern varieties of tourism: tutorial]. Kyiv: Znannya, 334 p. (in Ukrainian)

2. Putsenteilo P. (2007) Economica i organizatsiya turistic-gotelnogo pidpryemnitsa: navchalny posibnyk [Economics and organization of tourist and hotel entrepreneurship: tutorial]. Kyiv: Tsentr uchbovoy literature, $344 \mathrm{p}$. (in Ukrainian)

3. Tomczewska-Popowycz Natalia (2017) Active tourism and other close forms of tourism in Eastern European literature [Etnichny turism tha inshi blizki form tourism vie skhidnoyevropeysky literature]. "Przegląd Wschodnioeuropejski", vol. 8, nr 1, pp. 271-280. (in Ukrainian)

4. Wikipedia. Available at: www.uk.wikipedia.org/wiki/€вpeï

5. Official website of the festival. Available at: www.jewishpeople.in.ua

6. Association of Jewish Organizations and Communities of Ukraine. Available at: www.vaadua.org

7. Strategy for the return of Ukrainians. Available at: www.zn.ua 